\title{
IT Agility: Current State, Organizational Contingencies, and Future Research Avenues
}

\author{
Michael Yousif, MSc \\ Associate Researcher, Department \\ of Applied IT, University of \\ Gothenburg and Chalmers \\ University of Technology \\ Associate Director, Department of \\ RD Information, AstraZeneca \\ michael.yousif@astrazeneca.com
}

\author{
Johan Magnusson, PhD \\ Associate Professor, Department of \\ Applied IT, University of \\ Gothenburg and Chalmers \\ University of Technology, \\ Westerdal Oslo School of Art, \\ Communication and Technology \\ johan.magnusson@gu.se
}

\author{
Kalevi Pessi, PhD \\ Associate Professor, Department of \\ Applied IT, University of \\ Gothenburg and Chalmers \\ University of Technology \\ kalevi.pessi@gu.se
}

\begin{abstract}
Recent years increase in organizations' dependence on information technology has ushered in changing roles for IT departments and IT governance alike. Instead of being primarily focused on the continuous and cost efficient maintenance and support of existing resources, there is a need for a more balanced take on IT Governance which calls for an ambidextrous approach. This involves an increased focus on agility in terms of achieving both economies of scale and scope. This paper reports on a recent quantitative assessment of IT agility in Swedish Firms. Informed by contingency theory, the results are analyzed and discussed in relation to future research for IT agility. Our findings lead to six organizational contingencies expressed as six hypotheses that should be addressed within future IT agility research.
\end{abstract}

Keywords: IT Governance, IT Agility, IT Agility Assessment, Contingency Theory

\section{Introduction}

Organizations are increasingly dependent on the successful utilization and governance of Information Technology (IT) [1-4]. At the same time, the use of IT for both revenue generation and cost reduction [5], coupled with the incorporation of digital innovation into the very fabric of the business [6] results in an increased demand for IT departments to be agile in their internal delivery. This increased demand for agility is reverberated within the strategic management and information systems disciplines alike $[7,8]$.

In order for the IT organization to meet these new demands for increased agility, there is a need to adapt existing IT Governance [9, 10]. As noted by Gregory, Keil, Muntermann and Mähring [11] in their study of a major IT transformation program in a Fortune 200 bank, this involves a turn towards an ambidextrous approach within IT Governance, i.e. an increased ability of supporting both exploration and exploitation [12, 13]. This shift within IT Governance is also visible in the recent promotion of "Bimodal IT" by the industry analyst firm Gartner, where CIOs and IT departments will need to strive for mastering two modes of IT delivery, i.e. both swift and proactive innovation and cost efficient maintenance and support.

Previous research within IT Governance has highlighted the tendency for IT departments to primarily focus on aspects associated with cost efficient maintenance and support [14]. This implies that existing IT Governance may be regarded as optimized for non-agile delivery, with a tendency to strive for economies of scale at the cost of economies of scope [15].

While there is substantial research on what agility is and how organizations can become more agile, there has so far been relatively limited empirical research directed towards agility within internal IT departments. Several researchers have made calls for more empirical research on IT related agility [3], in particular related to the measurement and assessment of organizations' IT agility [16-18]. 
This paper addresses said issues and contributes to research through an empirical quantitative assessment of IT Agility practice. Using the findings of this assessment coupled with inspiration from contingency theory [19], the aim of the paper is to present current state of IT agility, discuss relevant organizational contingencies, and explore future avenues for research within IT agility. This is guided by the following research question(s):

What is the current state of IT Agility and which contingencies should be addressed in future research?

This is operationalized through a survey, conducted in the spring of 2015, directed towards IT professionals within Swedish firms, and a subsequent analysis of the findings utilizing previously identified contingencies.

The remained of the paper is organized accordingly: First, we present a brief review of previous research within IT Agility and Contingency theory, followed by a description of the research design and method. After this, we present the results of the survey followed by a discussion where we present a number of future research avenues for IT agility. We then end with limitations and next steps.

\section{Precursory findings}

\subsection{IT Agility}

Scholars are in strong agreement that the right and agile IS/IT capabilities can enhance business performance and also business agility [20-22]. These capabilities can enable the configuration and reconfiguration of an organization's different resources in a rapid and flexible manner helping the organization to sense and respond to changes in its environment [23]. This is referred to as the organization's IT agility [23-26].

Accordingly, IT agility is described as "the ability of Information Technology to support an organization to swiftly change businesses and business processes beyond the normal level of flexibility to effectively manage highly uncertain and unexpected, but potentially consequential internal and external events" [23, p. 38]. On the basis of this definition, van Oosterhout [23] presents a model for how IT agility should support business agility, in which IT agility needs to be aligned with three dimensions of business agility; sensing, responding and learning.

Sambamurthy, Wei, Lim and Lee [27, p. 2] define IT-enabled Organizational Agility as "an IT-enabled intermediate driving force of a firm's competitive success". They see two types of IT-enabled agility with different roles in generating sustainable competitive advantage; IT-enabled entrepreneurial agility which aims at creating new ideas and their applications beyond the boundaries of the organization, and IT-enabled adaptive agility which is about the organization's capability of coping with uncertainty and recover rapidly from disruption.

In another take, Tapanainen [28, p. 14] regards IT agility as "the ability of the IT function to sense external changes and respond internally and externally to requirements so arising". On the basis of this, Tapanainen considers IT agility as an umbrella term comprised of IT Function Agility (internal response dimension) and IT Business Partnership Agility (external response dimension). An agile IT function according to Tapanainen [28, p. 14] is "one that can sense changes in the organizational environment (and beyond), and is capable of adjusting and responding internally to those changes". An agile IT business partnership is an aligned partnership that continues to develop according to environmental requirements in order to provide the external response component in IT agility (ibid).

The definition of IT agility guiding this research is in line with the definition of Tapanainen [28], encompassing both the agilities of the IT function and the IT business interaction.

\subsection{Contingency theory}

The underlying assumption of contingency theory is that organizations are governed and managed by fitting the characteristics of the organization and its operating environment to a set of contingencies that reflect the current situation of the organization [29]. This implies that there is not one single optimal way of exerting management, decision-making, and leadership that would fit all organizations as different environments provide different antecedents [30]. The management literature brings up a broad spectrum of contingency variables covering both the external and internal aspects of the organization. In his analysis of contingency based research [19] focuses on contextual variables of the external environment (such as uncertainty, risk, hostility, complexity, and 
dynamism), technology (traditional and contemporary), organizational structure, size, strategy and national culture.

Sambamurthy and Zmud [31] disqualify the utilization of contingency theory through highlighting that it so far had failed to deliver any actionable insight in terms of informing the design of IT Governance. Despite this, several researchers such as $\mathrm{Wu}$, Straub and Liang [32], Banker, Wattal and Plehn-Dujowich [33] and Xue, Ray and Sambamurthy [15] have been successful in establishing empirical support for contingencies such as environmental dynamism and generic strategies within the field of IT Governance.

\section{Method}

\subsection{Research design}

The basis of the survey was the IT agility framework of Yousif, Pessi and Magnusson [34] as illustrated in Figure 1.

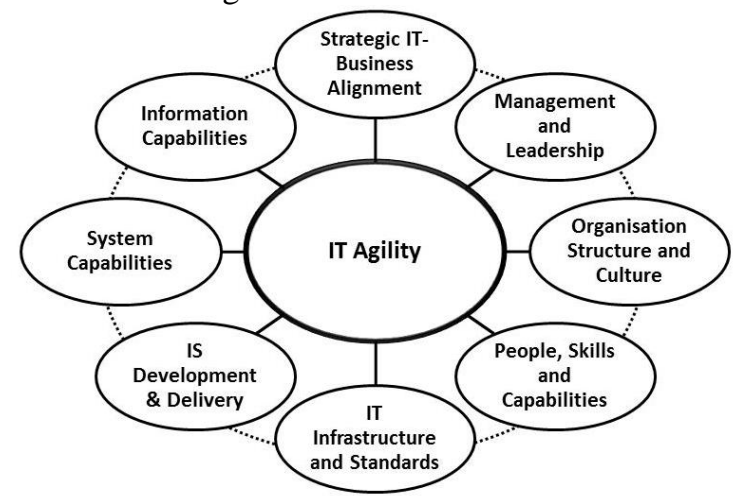

Figure 1: IT Agility Framework [34]

The framework consists of eight agility dimensions where each dimension is broken down into 5-10 characteristics or measurements adding up to 60 in total. The 60 agile characteristics in the framework are articulated as statements reflecting either a) states of how things are or should be in an agile IT organization, or b) features describing various aspects of an agile IT organization and its relation to business, and c) activities that should take place if an IT organization should become agile [34].

The following two reasons were mainly behind selecting this framework for conducting this assessment:
- The framework is recent and is well substantiated in the IT agility literature as it was developed based on the outcome of an extensive IT agility literature review including 53 sources published between 1991 and 2015 [34].

- The 60 IT agile characteristics in the framework are articulated in such a way [34] that they lend themselves well for becoming clearly defined measurements for evaluation in a quantitative survey which was our preferred assessment method.

Accordingly, the IT agility framework was converted into a web-based survey where the 60 characteristics in the framework were mapped directly into 60 questions in the survey. For each question, respondents were asked to assess three aspects; Importance (i.e. how important this characteristic is to the respondent's organization), Status (i.e. the extent to which this characteristic exists in the respondent's organization), Active Work (i.e. the extent to which respondent's organization works actively to achieve and/or improve this characteristic).

The exact wording of the assessment questions related to Importance, Status and Active Work and response alternatives (using Likert scale) are shown in figure 2 .

\begin{tabular}{|c|c|c|c|c|c|c|c|c|c|c|c|c|c|c|c|}
\hline \multirow{3}{*}{$\begin{array}{l}\text { For each } \\
\text { dimension }\end{array}$} & \multicolumn{5}{|c|}{ Importance } & \multicolumn{5}{|c|}{ Status } & \multicolumn{5}{|c|}{ Active Work } \\
\hline & \multicolumn{5}{|c|}{$\begin{array}{l}\text { Is this characteristic } \\
\text { important to your } \\
\text { organization? }\end{array}$} & \multicolumn{5}{|c|}{$\begin{array}{l}\text { Does this characteristic } \\
\text { exist in your } \\
\text { organization? }\end{array}$} & \multicolumn{5}{|c|}{$\begin{array}{c}\text { Is your organization } \\
\text { working actively to } \\
\text { achieve/sustain this } \\
\text { characteristic? }\end{array}$} \\
\hline & 善 & 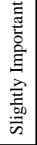 & 萻 & 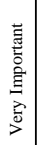 & 辛 & 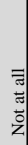 & 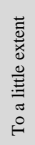 & 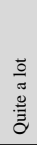 & 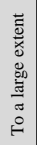 & 这 & 㻤 & 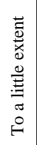 & 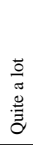 & 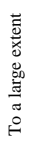 & 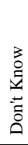 \\
\hline \multicolumn{16}{|l|}{\begin{tabular}{|l|} 
Characteristic 1 \\
\end{tabular}} \\
\hline \multicolumn{16}{|l|}{\begin{tabular}{|l|} 
Characteristic 2 \\
\end{tabular}} \\
\hline Etc. & & & & & & & & & & & & & & & \\
\hline
\end{tabular}

Figure 2: Survey design

The ideal sampling would have been probability sampling, i.e. a random sampling of Swedish organizations and IT professionals within them. This was deemed to be difficult to achieve, so instead we chose the method of purposive sampling which is a form of non-probability sampling in which the researcher aims to sample cases/participants in a strategic way, so that those sampled are relevant to the research questions that are being proposed [35].

Accordingly, we selected the members of the Swedish Computer Society to constitute a fair 
representation of our target population, i.e. IT professionals in Swedish organizations. This association is the biggest independent body for the ICT (Information and Communications Technology) professionals in Sweden, and covers the entire country with six local representations spanning over the whole of Sweden. The survey was sent out by the Swedish Computer Society to its members (10 354) as an email letter sponsored jointly by the society and the University of Gothenburg. 209 respondents representing 175 unique organizations completed the survey. These respondents covered a wide range of both private and public organizations with locations in at least 44 cities and towns in Sweden. The distribution and density of these locations seem to be fairly aligned with the population density of Sweden.

In order to address the low response rate of $2 \%$ and to further examine the external validity of our results, we applied the method of Radhakrishna and Doamekpor [36] that they advise using in cases of low response rate and where non-response bias analysis is not done. They recommend a method of comparing the group of early respondents (subjects who responded to the first mailing within the deadline date) with the group of late respondents (all other subjects who responded to subsequent mailings). If the difference on key variables is not significant, one can conclude that non-respondents are perhaps similar to late respondents and thus generalize the findings. This is based on what Miller and Smith [37] have claimed that non-respondents tend to be similar to late respondents. Following this recommendation, we compared our early respondent group (105 respondents who responded to the first email sent) to the late respondents (104 who responded to the following two emails). Testing the difference (using a two-tailed independent t-test) for the three key variables importance, status, and active work showed no significance difference between early and late respondents.

For calculating and reporting on IT agility Importance, Status, and Active Work levels, a composite/aggregated score of the answers' mean value per dimension was used.

\subsection{Method of analysis}

The various subgroups of our sample constituted the contingency factors in the study (e.g. size of the organizations, public/private organizations, etc.). Our decision of using the contingency theory variables to analyze our empirical findings is supported by the fact that the contingency theory recognizes the influence of organizational context on organizational governance [19]. In order to analyze the impact of the contingency factors, we utilized two-tailed independent T-tests.

\section{Results}

\subsection{Demographics of sample}

As seen in Table 1, the sample represents a wide range of global and national organizations spanning over the public sector as well as various industry sectors, ranging from healthcare, financial services, energy, materials, industrials, consumer products, to information technology, among others.

Table 1: The demographic distribution of the sample

\begin{tabular}{|c|c|c|}
\hline Sector & $\mathbf{N}$ & Percent \\
\hline Government / Public Sector & 74 & $35.4 \%$ \\
\hline Private Sector & 135 & $64.6 \%$ \\
\hline $\begin{array}{l}\text { - Energy and Power } \\
\text { Supply }\end{array}$ & 11 & $5.3 \%$ \\
\hline - $\quad$ Materials & 9 & $4.3 \%$ \\
\hline - Industrials & 8 & $3.8 \%$ \\
\hline - Consumer Discretionary & 11 & $5.3 \%$ \\
\hline - $\quad$ Consumer Staples & 7 & $3.3 \%$ \\
\hline - $\quad$ Health Care & 27 & $12.9 \%$ \\
\hline - Financials & 15 & $7.2 \%$ \\
\hline - Information Technology & 24 & $11.5 \%$ \\
\hline - Telecommunication & 4 & $1.9 \%$ \\
\hline - $\quad$ Other & 19 & $9.1 \%$ \\
\hline Total & 209 & $100.0 \%$ \\
\hline
\end{tabular}

\begin{tabular}{lcc} 
Size of organization & N & Percent \\
\hline Fewer than 100 & 32 & $15.3 \%$ \\
\hline Between $100-1000$ & 55 & $26.3 \%$ \\
\hline Between $1000-10000$ & 53 & $25.4 \%$ \\
\hline More than 10000 & 69 & $33.0 \%$ \\
\hline Total & $\mathbf{2 0 9}$ & $\mathbf{1 0 0 . 0 \%}$ \\
\hline
\end{tabular}

\begin{tabular}{lcc}
\hline Scale of operation & N & Percent \\
\hline Only in Sweden & 103 & $49.3 \%$ \\
\hline Globally & 106 & $50.7 \%$ \\
\hline Total & $\mathbf{2 0 9}$ & $\mathbf{1 0 0 . 0 \%}$ \\
\hline
\end{tabular}




\begin{tabular}{lcc} 
Functional placement & $\mathbf{N}$ & Percent \\
\hline IS/IT & 77 & $36.8 \%$ \\
\hline Interface IS/IT \& Business & 103 & $49.3 \%$ \\
\hline Business & 21 & $10.0 \%$ \\
\hline Other & 8 & $3.8 \%$ \\
\hline Total & $\mathbf{2 0 9}$ & $\mathbf{1 0 0 . 0 \%}$ \\
\hline & $\mathbf{N}$ & Percent \\
\hline Organizational hierarchy & 29 & $13.9 \%$ \\
\hline Upper management level & 34 & $16.3 \%$ \\
\hline Middle management level & 38 & $18.2 \%$ \\
\hline Lower management level & 108 & $51.7 \%$ \\
\hline None management level & $\mathbf{2 0 9}$ & $\mathbf{1 0 0 . 0 \%}$ \\
\hline Total & & \\
\hline Tenure & $\mathbf{N}$ & $\mathbf{P e r c e n t}$ \\
\hline Less than 1 year & 12 & $5.7 \%$ \\
\hline 1 - 3 years & 40 & $19.1 \%$ \\
\hline 4 - 5 years & 21 & $10.0 \%$ \\
\hline More than 5 years & 136 & $65.1 \%$ \\
\hline Total & $\mathbf{2 0 9}$ & $\mathbf{1 0 0 . 0 \%}$ \\
\hline
\end{tabular}

\subsection{Current state of IT agility}

As seen on Figure 3, IT agility is deemed important for the survey firms as the Importance variable ranges from 76.8 to 88.3 of 100 for the eight agility dimensions in the framework. This high degree of importance does not seem to match the current level of IT agility, as the Status variable for the eight dimensions ranges only between 46.2 to 57.6 of 100 . The amount of work undertaken in to achieve and improve IT agility does not either reflect the importance of it, as the level of the Active Work variable ranges between 50.5 and 61.2 of 100 for the eight dimensions.

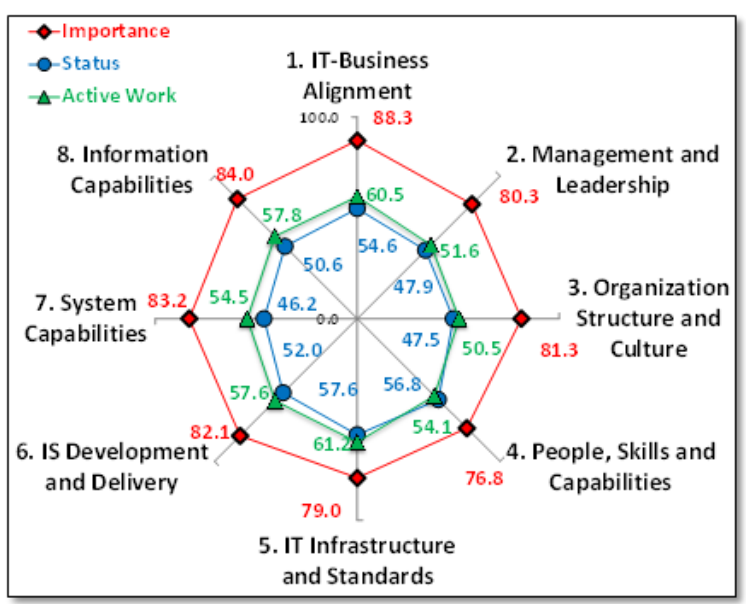

Figure 3: The aggregated results of IT Agility Importance, Status, and Active Work per dimension

\subsection{Contingencies of IT Agility}

As outlined in the Method chapter the various subgroups (characteristics) of our survey sample constituted the organizational contingency factors that we studied with regard to IT agility. Using a twotailed independent T-test, Table 2 shows with statistical significance whether IT agility is contingent or not upon each one of the sample subgroups/characteristics.

Table 2: Contingency analysis

\begin{tabular}{|l|l|l|}
\hline $\begin{array}{l}\text { Subgroup/ } \\
\text { Contingency }\end{array}$ & Finding & Statistics \\
\hline Sector & $\begin{array}{l}\text { No statistically } \\
\text { significant difference of } \\
\text { IT agility levels between } \\
\text { private and public sector } \\
\text { organizations }\end{array}$ & $\begin{array}{l}\text { T-value } \\
=0.133, \\
\text { P-value } \\
=0.05\end{array}$ \\
\hline Size & $\begin{array}{l}\text { Organizations with up to } \\
\text { 1000 employees showed } \\
\text { significantly higher IT } \\
\text { agility levels compared } \\
\text { to those with more than } \\
\text { 1000 employees }\end{array}$ & $\begin{array}{l}\text { T-value } \\
\text { P-value } \\
=0.05\end{array}$ \\
\hline $\begin{array}{l}\text { Scale of } \\
\text { operation }\end{array}$ & $\begin{array}{l}\text { No statistically } \\
\text { significant difference of } \\
\text { IT agility levels between } \\
\text { organizations with } \\
\text { global presence } \\
\text { compared to those only } \\
\text { operating in Sweden. }\end{array}$ & $\begin{array}{l}\text { T-value } \\
\text { P-value } \\
=0.05\end{array}$ \\
\hline
\end{tabular}




\begin{tabular}{|l|l|l|}
\hline $\begin{array}{l}\text { Subgroup/ } \\
\text { Contingency }\end{array}$ & Finding & Statistics \\
\hline Function & $\begin{array}{l}\text { No statistically } \\
\text { significant difference of } \\
\text { IT agility levels as } \\
\text { viewed by people } \\
\text { belonging to the IT } \\
\text { functions vs those } \\
\text { belonging to IT- } \\
\text { Business interaction } \\
\text { functions. }\end{array}$ & $\begin{array}{l}\text { T-value } \\
=0.533, \\
\text { P-value } \\
=0.05\end{array}$ \\
\hline Hierarchy & $\begin{array}{l}\text { IT agility is viewed } \\
\text { significantly higher by } \\
\text { people working in } \\
\text { managerial roles } \\
\text { compared to those } \\
\text { working in none- } \\
\text { managerial roles. }\end{array}$ & $\begin{array}{l}\text { T-value } \\
=0.002, \\
\text { P-value } \\
=0.05\end{array}$ \\
\hline Tenure & $\begin{array}{l}\text { No statistically } \\
\text { significant difference of } \\
\text { IT agility levels between } \\
\text { people with different } \\
\text { length of tenure. }\end{array}$ & $\begin{array}{l}\text { T-value } \\
=0.589, \\
\text { P-value } \\
=0.05\end{array}$ \\
\hline
\end{tabular}

\section{Discussion}

\subsection{General discussion}

The study reported in this paper constitutes, to the best of our knowledge, the first major empirical study of IT Agility. We believe that the relative low level of IT agility is not surprising given the many challenges and obstacles that researchers $[18,22,38]$ as well as practitioners have reported not only with regard to the organization's ability to comprehend the broad meaning of IT agility, but even more importantly, to the organization's ability to operationalize, drive, and achieve higher levels of IT agility. Furthermore, we propose that these empirical findings should not be discussed and explained solely from the agility perspective (i.e. only agility vs. rigidity) but there is a need to consider the view that we outlined in the introduction of this paper, namely that the question of IT agility is to be studied and balanced together with other relevant and sometimes ambidextrous organizational perspectives such as efficiency, economies of scale, innovation ability, and others [5, 11, 15]. Hence, IT agility is not an isolated topic and these empirical results are to be seen as context-dependent, and even though we did not ask our survey respondents to position their organizations in terms of the mentioned perspectives, we think that the demographical construct of our respondent group covers indirectly some of these organizational perspectives plus a number of other relevant aspects. So all in all, the demographic entities of our sample provides a good set of valid contextual variables that are worth discussing and looking more into with regard to future IT agility research. This is done in the next section.

\subsection{Contingencies for future research}

For each contingency factor we briefly discuss and propose hypotheses to aid future research.

\section{Public vs private sector organizations}

According to the findings of our study, whether the organization is public or private doesn't seem to have an impact on the level of IT agility. Hence our proposed hypothesis for future research is:

H1: IT agility is not contingent upon sectoral belonging.

\section{Size of the organization}

Previous studies have shown that the level of bureaucratization increases over time, and hence this would create a situation where we would expect to see organization size as a contingency factor for Agility [39]. The findings in this study support this claim, and hence our hypothesis for future research is:

H2: IT Agility is negatively associated with increased organization size.

\section{National vs global operating environment}

Our findings suggest no impact on levels of IT agility between organizations with global presence and those only operating on a national level. This seems reasonable as many of the organizations operating only in Sweden are public and governmental organizations, and we could see earlier that IT agility levels were not impacted by whether an organization is public or private. Thus our hypothesis for future research is:

H3: IT Agility is not contingent upon the geographical spread of the organization. 


\section{Employees' functional placement}

Our data suggest no difference in how levels of IT agility are perceived by people belonging to the IT function compared to those belonging to IT-Business interfacing functions. We believe that such a consistent view on the perception of IT agility by IT people in different functions is a positive thing. Thus our hypothesis for future research is:

H4: IT personnel's perception of IT Agility level is not contingent upon the functional positioning.

\section{Employees' organization hierarchy placement}

Our study findings suggest that people in managerial roles perceive levels of IT agility to be higher than those of none managerial roles. This gap in how IT agility is viewed by these two groups of employees constitutes a serious inconsistency and disconnect and is very likely to have negative impact on the organization's efforts to improve agility. Thus our hypotheses for future research are:

H5: IT personnel's perception of IT Agility capability is positively associated with higher hierarchal positioning.

\section{Tenure}

Data from our empirical study show no difference on how IT agility levels are viewed by employees with different length of service. Thus our hypothesis for future research is:

H6: IT personnel's perception of IT Agility level is not contingent upon tenure.

\section{Limitations}

The main weaknesses of our empirical IT agility assessment is the non-random sampling together with the low response rate. These two factors can be viewed as constraints to our ability to generalize the findings of our study.

As for the selection method, probability sampling would have been the optimal choice. However, we believe as outlined in the Method chapter that our choice of purposive sampling targeting the members of the Swedish Computer Society provides an acceptable level of representation as the society is the biggest association for ICT professionals in Swedish organizations with six local representations spanning over the entire country.
As for the low response rate, we knew from the outset that a survey of this magnitude (three evaluation aspects of 60 measurements, i.e. 180 questions) would be very demanding in terms of time and effort to complete. However, and considering the number of organizations and their sectorial and geographical distribution that our 209 respondents represent as well as the alternative analysis we carried out to compensate for the missing nonrespondent analysis, we would like to argue that the results of our survey give some credible indications and provide some valuable knowledge about IT agility in Swedish organizations.

\section{Next steps}

The IT agility survey we conducted should ultimately be seen as a step towards helping the business to better comprehend how it can gain more value out of IT. In the light of this, extending this kind of assessment to cover business functions is essential. But what is even more important is to evaluate IT agility from the view point of the entire organization and in doing so, taking into account contextual variables such as the ones we covered as well as other relevant ones.

\section{Acknowledgment}

The researchers would like to sincerely thank the Swedish Computer Society, in particular Thure Bergström and Sara Hertzman for adopting and promoting our survey.

The researchers would also like to express their thanks to the Marianne and Marcus Wallenberg foundation for the monetary support necessary for conducting this research.

\section{References}

[1] Rowlands, B., Haes, S.D., and Grembergen, W.V.: 'Exploring and developing an IT governance culture framework'. Proc. Thirty Fifth International Conference on Information Systems, Auckland, 2014

[2] Butler, B.S., and Gray, P.H.: 'Reliability, Mindfulness, and Information Systems', MIS Quarterly, 2006, 30, (2), pp. 211-224

[3] Van Oosterhout, M., Waarts, E., and Van Hillegersberg, J.: 'Change factors requiring agility and implications for 
IT', European Journal of Information Systems, 2006, 15, (2), pp. 132-145

[4] Saunders, A., and Brynjolfsson, E.: 'Valuing Information Technology Related Intangible Assets', MIS Quarterly, 2016, 40, (1), pp. 83

[5] Mithas, S., and Rust, R.T.: 'How Information Technology Strategy and Investments Influence Firm Performance: Conjecture and Empirical Evidence', MIS Quarterly, 2016, 40, (1), pp. 223

[6] Yoo, J.C., Lim, T.K., Koh, K.H., and Park, W.H.: 'Arthroscopic perspective of the tendinous insertion of the pectoralis minor and correlation with MRI: A case report', Journal of Shoulder and Elbow Surgery, 2010, 19, (4), pp. e19-e23

[7] Lewis, M.W., Andriopoulos, C., and Smith, W.K.: 'Paradoxical Leadership to Enable Strategic Agility', California Management Review, 2014, 56, (3), pp. 58-77

[8] Liu, F., and Maitlis, S.: 'Emotional Dynamics and Strategizing Processes: A Study of Strategic Conversations in Top Team Meetings: Emotional Dynamics and Strategizing Processes', Journal of Management Studies, 2014, 51, (2), pp. 202-234

[9] Weill, P., and Ross, J.W.: 'IT governance on one page', Center for Information Systems Research Working Paper 349, Massachusetts Institute of Technology., 2004

[10] Tiwana, A., and Kim, S.K.: 'Discriminating IT Governance', Information Systems Research, 2015, 26, (4), pp. 656

[11] Gregory, R.W., Keil, M., Muntermann, J., and Mähring, M.: 'Paradoxes and the Nature of Ambidexterity in IT Transformation Programs', Information Systems Research, 2015, 26, (1), pp. 57-80

[12] March, J.G.: 'Exploration and Exploitation in Organizational Learning', Organization Science, 1991, 2, (1), pp. 71-87

[13] Birkinshaw, J., and Gibson, C.: 'Building Ambidexterity Into an Organization', MIT Sloan Management Review, 2004, 45, (4), pp. 47

[14] Magnusson, J., Bygstad, B., Centre for Business, S., University of, G., Företagsekonomiska, i., Göteborgs, u., School of Business, E., Law, Handelshögskolan, Företagsekonomiska institutionen, R., Centrum för, a., Department of Business, A., and Department of Business Administration, A.: 'Why I act differently: studying patterns of legitimation among CIOs through motive talk', Information Technology \& People, 2013, 26, (3), pp. 265282
[15] Xue, L., Ray, G., and Sambamurthy, V.: 'Efficiency or innovation: how do industry environments moderate the effects of firms' IT asset portfolios?', MIS quarterly, 2012, $36,(2)$, pp. $509-528$

[16] Arteta, B.M., and Giachetti, R.E.: 'A measure of agility as the complexity of the enterprise system', Robotics and Computer Integrated Manufacturing, 2004, 20, (6), pp. 495-503

[17] Rdiouat, Y., Bahsani, S., Lakhdissi, M., and Semma, A.: 'Measuring and Improving Information Systems Agility Through the Balanced Scorecard Approach', International Journal of Computer Science Issues (IJCSI), 2015, 12, (5), pp. 58

[18] Sengupta, K., and Masini, A.: 'IT agility: striking the right balance', Business Strategy Review, 2008, 19, (2), pp. $42-48$

[19] Chenhall, R.H.: 'Management control systems design within its organizational context: findings from contingency-based research and directions for the future', Accounting, Organizations and Society, 2003, 28, (2), pp. 127-168

[20] Baskerville, R.L., Mathiassen, L., Pries-Heje, J., and DeGross, J.I.: 'Business agility and information technology diffusion', IFIP Advances in Information and Communication Technology, 2005, 180

[21] Gallagher, K.P., and Worrell, J.L.: 'Organizing IT to promote agility', Information technology and management, 2008, 9, (1), pp. 71-88

[22] Melarkode, A., From-Poulsen, M., and Warnakulasuriya, S.: 'Delivering Agility Through IT', Business Strategy Review, 2004, 15, (3), pp. 45-50

[23] van Oosterhout, M.: 'Business agility and information technology in service organizations' (Doctoral dissertation. Erasmus Research Institute of Management (ERIM), Rotterdam, Holland, 2010. 2010)

[24] Byrd, T.A., and Turner, D.E.: 'An exploratory examination of the relationship between flexible IT infrastructure and competitive advantage', Information \& Management, 2001, 39, (1), pp. 41-52

[25] Overby, E., Bharadwaj, A., and Sambamurthy, V.: 'Enterprise agility and the enabling role of information technology', European Journal of Information Systems, 2006, 15, (2), pp. 120-131

[26] Sambamurthy, V., Bharadwaj, A., and Grover, V.: 'Shaping Agility through Digital Options:

Reconceptualizing the Role of Information Technology in Contemporary Firms', MIS Quarterly, 2003, 27, (2), pp. 237-263 
[27] Sambamurthy, V., Wei, K.-K., Lim, K., and Lee, D.: 'IT-enabled organizational agility and firms' sustainable competitive advantage', ICIS 2007 Proceedings (2007): 91

[28] Tapanainen, T.: 'Information Technology (IT) managers' contribution to IT agility in organizations-views from the field', Doctoral dissertation. University of Turku School of Economics, Turku, Finland, 2012

[29] Donaldson, L.: 'The contingency theory of organizations' (Sage, Thousand Oaks, CA, 2001. 2001)

[30] Grötsch, V.M., Blome, C., and Schleper, M.C.: 'Antecedents of proactive supply chain risk management a contingency theory perspective', International Journal of Production Research, 2013, 51, (10), pp. 2842

[31] Sambamurthy, V., and Zmud, R.W.: 'Arrangements for information technology governance: A theory of multiple contingencies', MIS quarterly, 1999, pp. 261-290

[32] Wu, S.P.-J., Straub, D.W., and Liang, T.-P.: 'How information technology governance mechanisms and strategic alignment influence organizational performance: Insights from a matched survey of business and IT managers', Mis Quarterly, 2015, 39, (2), pp. 497-518

[33] Banker, R.D., Wattal, S., and Plehn-Dujowich, J.M.: 'R\&D Versus Acquisitions: Role of Diversification in the Choice of Innovation Strategy by Information Technology Firms, Journal of Management Information Systems, 2011, 28, (2), pp. 109-144

[34] Yousif, M., Pessi, K., and Magnusson, J.: 'IT Agility: A Proposed and Evaluated Framework', Twenty-second Americas Conference on Information Systems, San Diego, 2016

[35] Bryman, A.: 'Social research methods' (Oxford university press, 2012)

[36] Radhakrishna, R., and Doamekpor, P.: 'Strategies for generalizing findings in survey research', Journal of Extension, 2008, 46, (2), pp. 1-4

[37] Miller, L.E., and Smith, K.L.: 'Handling nonresponse issues', Journal of extension, 1983, 21, (5), pp. 45-50

[38] Roberts, N., and Grover, V.: 'Leveraging information technology infrastructure to facilitate a firm's customer agility and competitive activity: An empirical investigation', Journal of Management Information Systems, 2012, 28, (4), pp. 231-270

[39] Harraf, A., Wanasika, I., Tate, K., and Talbott, K.: 'Organizational Agility', Journal of Applied Business Research, 2015, 31, (2), pp. 675 